\begin{tabular}{l|l} 
Jurnal Eksplorasi Akuntansi & $\begin{array}{l}\text { Vol. 1, No 1, Seri D, Februari 2019, Hal 445-458 } \\
\text { ISSN : 2656-3649 (Online) } \\
\text { http://jea.ppj.unp.ac.id/index.php/jea/issue/view/4 }\end{array}$
\end{tabular}

\title{
ANALISIS FRAUD TRIANGLE UNTUK MENDETEKSI KECURANGAN LAPORAN KEUANGAN
}

(Studi Empiris Pada Perusahaan Manufaktur Yang Terdaftar di BEI Periode 2014-2017)

\author{
Septia Dwijayani ${ }^{1}$, Nurzi Sebrina ${ }^{2}$ Halmawati $^{3}$ \\ ${ }^{1)}$ Alumni Jurusan Akuntansi Fakultas Ekonomi, Universitas Negeri Padang \\ ${ }^{2,3)}$ Jurusan Akuntansi Fakultas Ekonomi, Universitas Negeri Padang \\ *Korespondensi: septiadwijayani456@gmail.com
}

\begin{abstract}
This study aims to obtain empirical evidence of fraud triangle in detecting fraudulent financial statements. The variabbles of fraud triangle are pressure, opportunity, and rasionalization then divided into six independent sub-variables. Namely financial stabilty which is proxied by asset change ratio (achange), personal financial need which is proxied by oship, external pressure which is proxied by the ratio of changes in debt (lev), financial targets that are proxied by ROA (ROA), the nature of industry that is proxied by inventory (inventory), effective monitoring that is proxied by the proportion of independent commissioners (ind), and rasionalization proxied by auditor change (auchange). The population of this study are manufacturing companies listed on the Indonesia Stock Exchange for the period 2014-2017. the total sample of the study was 32 companies. Data analysis method uses logistic regression analysis. The results of this study indicate that financial stability variables, personal financial need, external pressure, nature of industry, effective monitoring, and rationalization have no effect on fraudulent financial statements. the results of this study can prove that financial targets have an effect on fraudulent financial statements. Further researchers can develop this research by adding sub-variables or using other proxies.
\end{abstract}

Keywords: fraud triangle; fraud; financial statemnts fraud;

How to cite (APA $6^{\text {th }}$ style)

Dwijayani, S., Sebrina, N. \& Halmawati. (2019). Analisis Fraud Triangle untuk Mendeteksi Kecurangan Laporan Keuangan (Studi Empiris pada Perusahaan Manufaktur Yang Terdaftar di BEI Periode 2014-2017). Jurnal Eksplorasi Akuntansi, 1(1) Seri D, 445458.

\section{PENDAHULUAN}

Ikatan Akuntansi Indonesia Pernyataan Standar Akuntansi Keuangan No.1 Tahun 2009, menyatakan tujuan laporan keuangan adalah untuk memberikan informasi tentang posisi keuangan, kinerja, dan arus kas suatu entitas yang bermanfaat bagi pengguna laporan keuangan dalam membuat keputusan ekonomi. Informasi bermanfaat tersebut menggambarkan kinerja perusahaan yang harus memiliki karektristik kualitatif diantaranya, dapat dipahami, relevan, reliability, dan dapat diandalkan. Laporan keuangan menjadi wadah komunikasi bagi perusahaan 
dengan pihak eksternal, sehingga perusahaan harus menyajikan informasi yang akurat, relevan, dan bebas dari kecurangan. Laporan yang akurat, relevan, dan bebas dari kecurangan akan bermanfaat bagi pengguna laporan keuangan dalam mengambil keputusan,namun masih banyak perusahaan yang mengabaikan karektristik kualitatif dari tujuan laporan keuangan sehingga kecurangan dalam laporan keuangan masih banyak terjadi.

Fraud atau kecurangan secara umum diartikan sebagai tindakan yang sengaja dilakukan untuk memperoleh keuntungan secara material dan non material. Menurut Association of Certified Fraud Examiner (1998) dalam Ernts dan Young LPP (2009) fraud tindakan kekeliruan yang dilakukan perseorangan atau badan yang mengetahui bahwa akibat kekeliruan tersebut akan menimbulkan kerugian bagi individu, perusahaan, maupun pihak lain. Kecurangan pelaporan keuangan merupakan suatu perbuatan yang sengaja dilakukan oleh perusahaan untuk menyesatkan pengguna laporan keuangan, dengan merekayasa nilai material dari laporan keuangan.

Skandal akuntansi telah meluas, seperti yang terjadi di Amerika. Spathis (2002) menjelaskan bahwa kecurangan akuntansi yang menimpa USA menimbulkan kerugian yang sangat besar hampir seluruh industri. Tahun 2001 di USA terjadi kasus Enron, yaitu perusahaan yang merupakan gabungan dari InterNoth dan Houston Natural gas diperkirakan menimbulkan kerugian bagi Enron sebesar US\$50 miliar dan kerugian investor sebesar US\$32 miliar, serta ribuan pegawai Enron harus rela kehilangan dana pensiun yang diperkirakan kurang lebih US\$1 miliar. Enron melakukan kecurangan laporan keuangan dengan mencatat adanya keuntungan sebesar US\$600 juta sedangkan pada saat itu Enron sedang mengalami kerugian. Motivasi Enron melakukan kecurangan adalah karena keinginan perusahaan supaya sahamnya tetap diminati oleh investor.

Kasus penyimpangan akuntansi juga tidak terhindar di Indonesia. OJK mencatat jumlah kasus penyimpangan ketentuan perbankan (PKP) pada tahun 2017 mencapai 22 kasus. Pelaku yang berbuat tindak pidana mencapai 66 orang. Contoh lainnya adalah kasus dugaan korupsi anggaran PT Perusda Loteng Bersatu senilai Rp1 miliar. Pada tahun 2017, Kejaksaan Negeri Praya menetapkan Direktur Keuangan Prusda Loteng Bersatu berinisal AZ sebagai tersangka. Bulan Mei tahun 2018, di situs Tirto.id PT Sunprima Nusantara Pembiayan (SNP-Finance) yang berusia kurang lebih 18 tahun ternyata berada diambang kepailitan. Otoritas jasa keuangan membekukan kegiatan usaha SNP-Finance karena perseroan gagal membayar bunga MTN senilai Rp6,75 miliar pada 14 mei tahun 2018 melalui Surat Deputi Komisioner Pengawas IKNB II No. S-247/NB.2/2018. Diduga pihak SNP-Finance memberikan laporan keuangan fiktis, sehingga perusahaan pemeringkat dan auditor tidak mengeluarkan peringatan sebelum gagal bayar terjadi.

Pendeteksian terhadap kecurangan laporan keuangan belum mendapat titik terang, karena berbagai motivasi yang melatarbelakanginya. Teori Cressey (1953) dalam Skousen et al (2008) mengatakan bahwa ada tiga kondisi yang selalu hadir dalam tindakan fraud yaitu pressure, opportunity, dan rasionalization. Penelitian tentang fraud triangle masih menghasilkan temuan yang tidak konsisten. Penelitian yang dilakukan oleh Skousen et al (2009) yang menguji tentang efektivitas pengadopsian fraud risk factor framework oleh Cressey (1953) dalam SAS No. 99 untuk mendeteksi financial statement fraud. Hasil pnelitiannya membuktikan bahwa pertumbuhan aset yang cepat, pembiayaan eksternal berpengaruh terhadap kecurangan laporan keuanga. Hasil penelitian ini tidak membuktikan bahwa rasionalisai berpengaruh terhadap kecurangan laporan keuangan. 
Penelitian di Indonesia juga dilakukan oleh Tiffani, Laila dan Marfuah (2015), Sukirman dan Maylia (2013), Widarti (2015), Ratmono, Dwi et al (2014), Rani (2016) tetapi penelitian tersebut belum menghasilkan temuan yang konsisten, sehingga diperlukan penelitian lebih lanjut. Berdasarkan alasan dan latar belakang tersebut peneliti tertarik untuk melakukan penelitian tentang "Analisis Fraud Triangle untuk Mendeteksi Kecurangan Laporan Keuangan (Studi Empiris pada Perusahaan Manufaktur yang terdafar di Bursa Efek Indonesia Periode 20142017)".

\section{REVIU LITERATUR DAN HIPOTESIS \\ Teori Keagenan}

Jensen dan Mecklin (1976) mengatakan bahwa teori keagenan adalah hubungan keagenan antara pemilik dengan manajer. Teori keagenan ini adalah teori yang mendasari para pelaku bisnis di perusahaan. Pemilik sebagai principal menginginkan laba yang tinggi di perusahaannya, sedangkan manajer sebagai agent menginginkan kompensasi yang besar atas hasil kerjanya. Perbedaan tujuan antara pemilik dengan manajer ini menyebabkan adanya conflict of interest. Teori ini menjelaskan bahwa permasalahan yang timbul antara Pemilik dengan manajer akibat asimetri informasi.

Manajer sebagai penerima amanat harusnya bekerja untuk pemilik, namun kenyataannya manajer bekerja untuk kepentingan pribadi. Conflic of interest yang terjadi diantara kedua belah pihak menyebabkan manajer mendapat tekanan untuk mendapatkan cara agar kinerja perusahaan terus meningkat dengan harapan pemilik memberikan apresiasi berupa kompensasi yang tinggi. Manajer berpeluang melakukan kecurangan laporan keuangan atas akses infomasi yang mudah didapatkannya (Rani, 2016).

\section{Fraud}

Commenwalth Fraud Control Guideline Australia (2009) mengatkan fraud adalah memperoleh keuntungan dengan penipuan/kecurangan, defenisi ini meliputi antara lain: (1) pencurian; (2) mendapatkan property, keuntungan financial, dan keuntungan lainnya dengan menipu; (3) menghindari atau melaksanakan kewajiban dengan kecurangan;(4) memebrikan informasi yang menyesatkan kepada publik; (5) membuat, menggunakan, atau memiliki dokumen yang palsu; (6) penyuapan, korupsi, atau penyalahgunaan jabatan; (7) menggunakan computer, kendaraan, telepon, dan properti publik yang tidak sah; (8) tindakan yang menyebabkan kebangkrutan; (9) dan segala tindakan kecurangan lainnya.

Donal Cressey (1953) dalam penelitiannya menyimpulkan bahwa ada tiga kondisi yang menyebakan seseorang melakukan kecurangan. Tiga kondisi tersebut adalah tekanan (pressure), kesempatan (opportunity), dan rasionalisasi (rasionalization). Ketiga konsep ini disebut dengan fraud triangle. Seseorang melakukan kecurangan disebakan karena adanya tekanan. Empat macam kondisi tekanan yang menyebabkan seseorang melakukan kecurangan adalah financial stability, external pressure, personal financial need, dan financial target (SAS No.99). Tekanan terhadap kebutuhan keuangan merupakan penyebab paling utama dalam melakukan kecurangan laporan keuangan. Kecurangan terjadi karena adanya kesempatan dan peluang. Umumnya pelaku kecurangan lebih banyak dilakukan oleh manajemen dibanding karyawan. Tiga kondisi yang ada dalam peluang ini. Tiga kondisi tersebut aalah nature of industry, effective monitoring, dan organizational structure (SAS No.99).

Rasionalisasi menjadi hal penting dalam kecurangan laporan keuangan di mana pelaku membela dirinya terhadap yang dilakukannya adalah benar. Rasionalisasi merupakan bagian 
segita kecurangan yang sulit untuk diukur. Pelaku bisnis yang tidak jujur lebih mudah merasionalisasi kecurangannya.Rasionalisasi diperlukan agar sipelaku dapat mencerna perilakunya yang melawan hukum untuk tetap mempertahankan jati diirnya sebagai orang yang dipercaya (Tuannakotta, 2014:12).

Albrect et al (2010) menyatakan, rasionalisasi yang sering terjadi ketika melakukan fraud antara lain (1) aset itu sebenarnya milik saya, (2) saya hanya meminjam dan akan membayarnya kembali, (3) tidak ada pihak yang dirugikan, (40 ini dilakukan untuk sesuatu yang mendesak, (5) kami akan memperbaiki pembukuan setelah masalah keuangan ini selesai, (6) saya rela mengorbankan reputasi dan integritas saya asal itu dapat meningkatkan standard hidup saya.

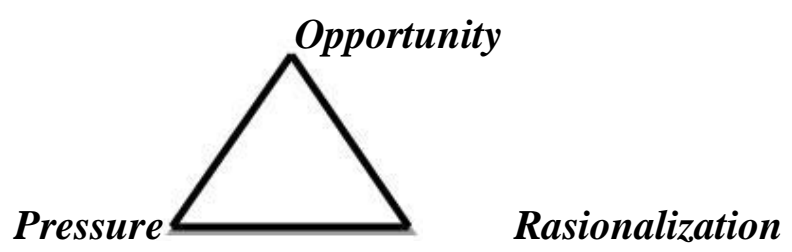

Gambar 1.

Fraud Triangle

(Laila,Tiffani dan Marfuah, 2015)

Skousen et. al. (2009) melakukan penelitian empiris tentang efektifitas teori Cressey (1953) mengenai kerangka faktor resiko kecurangan yang ditetapkan dalam SAS No. 99 untuk mendeteksi kecurangan laporan keuangan. Hasil penelitiannya yaitu pertumbuhan aset yang cepat, peningkatan kebutuhan uang tunai, dan pembiayaan eksternal yang positif berkaitan dengan kemungkinan terjadinya fraud. Kepemilikan saham eksternal dan internal serta kontrol dewan direksi juga terkait dengan fraud. Skousen et al. (2009) juga menemukan bahwa proporsi anggota audit independen berpengaruh negatif terhadap terjadinya kecurangan.

Lou dan Wang (2009) melakukan penelitian untuk menguji faktor resiko dari fraud triagle. Hasil penelitiannya yaitu kecurangan laporan keuangan berkaitan dengan salah satu kondisi yaitu tekanan keuangan dari suatu perusahaan, pertanyaan yang lebih terhadap integritas manajemen, atau memburuknya hubungan perusahaan dengan auditornya. Aghghaleh, Iskandar, dan Mohamed (2014) melakukan penelitian tentag resiko kecurangan fraud triangle di Malaysia. Metode yang dilakukan oleh mereka adalah metode regresi logistik sederhana berdasarkan contoh faktor resiko. Hasil dari penilitian ini adalah tekanan yang diproksikan dengan Piutang dan leverage memiliki pengaruh signifikan positif terhadap kecurangan laporan keuangan.

Ratmono,dkk (2014) meneliti tentang dapatkah teori fraud triangle menjelaskan kecurangan dalam laporan keuangan. Metode yang digunakan dalam penelitian ini adalah metode regresi logistik sederhana. Hasil yang didapat dari penelitian ini adalah proksi SALTA berpengaruh negatif dan signifikan terhadap kecurangan laporan keuangan. Sukiman dan Sari (2013) penelitiannya tentang mendeteksi kecurangan dengan basis teori fraud triangle. Metode yang digunakan adalah analisis regresi logistik. Hasil penelitiannya yaitu dalam rasionalisasi hanya satu proksi yang masuk ke dalam model yaitu variabel audit report. Kesimpulannya, semakin tinggi audit report, maka probabilitas perusahaan melakukan fraud juga semakin tinggi.

Marfuah dan Tifani (2015) melakukan penelitian tentang deteksi financial statement fraud dengan analisis fraud triangle. Hasil dari penelitian ini menunjukkan hasil bahwa ada pengaruh positif antara financial stability (achange) dan external pressure (lev) terhadap 
financial statement fraud. Sementara effective monitoring (ind) memiliki pengaruh negatif terhadap financial statement fraud. Hasil penelitian Marfuah dan Tifani memberi dukungan kepada fraudt triangle theory dalam menjelaskan fenomena financial fraud statements.

Norbarani (2013) juga melakukan penelitian yang bertujuan untuk mendeteksi kecurangan laporan keuangan berdasarkan analisis fraud triangle yang diadopsi dalam SAS No. 99. Hasil penelitiannya menunjukkan bahwa variabel external pressure yang diproksikan dengan rasio arus kas bebas memiliki hubungan negatif dengan financial statement fraud. Penelitian ini juga menunjukkan bahwa variabel financial target yang diproksikan dengan Return on Asset memeiliki hubungan positif dengan financial statement fraud. Penelitian ini tidak memberikan bukti bahwa variabel financial stability yang diproksikan dengan rasio perubahan total aset, variabel personal financial need yang diproksikan dengan rasio kepemilikan saham oleh orang dalam memiliki pengaruh terhadap financial statement fraud.

Financial stability merupakan keadaan yang menggambarkan kondisi keuangan yang stabil (Skousen et al. 2009). Manajer mendapat tekanan untuk melakukan kecurangan laporan keuangan ketika menghadapi kondisi ketidak stabilan keuangan perusahaan (SAS No. 99, dalam AICPA 2002). Manajer harus berusaha menunjukkan agar perusahaan bisa mengelola aset dengan baik sehingga menghasilkan laba yang tinggi. Bentuk manipulasi yang sering digunakan adalah yang berkaitan dengan pertumubuhan aset (Skousen et al, 2009). Semakin besar rasio perubahan total aset (achange) suatu perusahaan maka kemungkinan perushaan melakukan kecurangan laporan keuangan.

Penelitian yang telah dilakukan menghasilkan perbedaan dan hasil yang belum konsisten. Penelitian ini bertujuan untuk melihat bukti empiris fraud triangle dalam mendeteksi kecurangan laporan keuangan. Oleh karena itu, penelitian ini mengajukan hipotesis sebagai berikut:

H1: Financial Stability berpengaruh terhadap kecurangan laporan keuangan

H2: Personal financial need berpengaruh terhadap kecurangan laporan keuangan

H3: Ekxternal pressure berpengaruh terhadap kecurangan laporan keuangan

H4: ROA berpengaruh terhadap kecurangan laporan keuangan

H5: Nature of industry berpengaruh terhadap kecurangan laporan keuangan.

H6: Effective monitoring berpengaruh terhadap kecurangan laporan keuangan

H7: rasionalization berpengaruh terhadap kecurangan laporan keuangan

\section{KERANGKA KONSEPTUAL}

Berdasarkan penjelasan dari berbagai teori-teori yang tekah dijabarkan penulis menyusun kerangka konseptual untuk penelitian sebagai berikut:

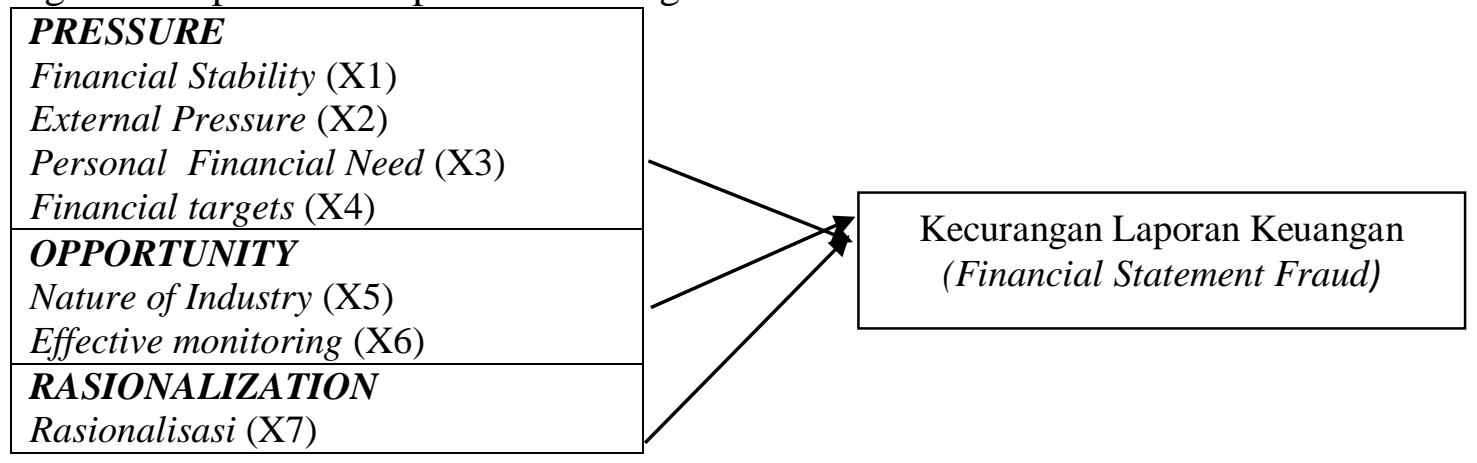

Gambar 2. Kerangka Komseptual 


\section{METODE PENELITIAN}

Penelitian ini termasuk penelitian kausatif. Tujuan penelitian kausatif adalah untuk mengetahui hubungan pengaruh antara variabel independen terhadap variabel dependen. Populasi dan sampel dalam penelitian ini adalah perusahaan yang terdaftar di Bursa Efek Indonesia periode 20142017. Pengambilan sampel dalam penelitian ini dilakukan dengan teknik purposive sampling yaitu pemilihan sampel berdasarkan kriteria tertentu. Jenis data yang digunakan dalam penelitian ini adalah data sekunder. Teknik yang digunakan dalam penelitian ini adalah teknik dokumentasi dengan melihat laporan keuangan dan laporan tahunan sampel. Data diperoleh melalui situs resmi BEI (www.idx.co.id).

Penelitian ini menggunakan kecurangan laporan keuangan sebagai variabel dependen yang diukur menggunakan model Beneish M-Score (Beneish, 1997). Model tersebut adalah sebagai berikut:

\section{M-Score $=4.84+0.920 \mathrm{DSRI}+0.528 \mathrm{GMI}+0.404 \mathrm{AQI}+0.892 \mathrm{SGI}+0.115 \mathrm{DEPI}+-0.172 \mathrm{SGAI}+-$ 0.327LVGI+4.697TATA}

Jika hasil Beneish M-Score lebih besar dari -2.22, maka perusahaan tersebut digolongkan kepada fraud. Sedangkan jika skor lebih kecil dari -2.22, maka perusahaan tersebut digolongkan kepada perusahaan yang tidak melakukan fraud. Perusahaan yang melakukan fraud diberi skor 1 dan perusahaan yang tidak melakukan fraud diberi skor 0 .

Tabel 1

Rasio keuangan untuk mengukur Beneish M-Score

\begin{tabular}{|c|c|c|}
\hline No & Rasio Keuangan & Rumus \\
\hline 1 & $\begin{array}{l}\text { Day Sales in Receivable Index } \\
\text { (DSRI) }\end{array}$ & $D S R I=\frac{\text { Receivables }_{\mathrm{t}} / \text { sales }_{\mathrm{t}}}{\text { Receivables }_{\mathrm{t}-1} / \text { sales }_{\mathrm{t}-1}}$ \\
\hline 2 & Gross Margin Index (GMI) & $G M I=\frac{\text { Sales }_{\mathrm{t}-1}-\mathrm{COG}_{\mathrm{t}-1} / \operatorname{sales}_{\mathrm{t}-1}}{\text { Sales }_{\mathrm{t}}-\mathrm{COG}_{\mathrm{t}} / \mathrm{sales}_{\mathrm{t}}}$ \\
\hline 3 & Aset Quality Index (AQI) & $A Q I=\frac{1-\left(\mathrm{CA}_{\mathrm{t}}+\mathrm{PPE} \mathrm{E}_{\mathrm{t}} / \mathrm{TA}_{\mathrm{t}}\right.}{1-\left(\mathrm{CA}_{\mathrm{t}-1}+\frac{P \mathrm{PE}_{\mathrm{t}-1}}{\mathrm{TA}_{\mathrm{t}-1}}\right)}$ \\
\hline 4 & Sales Growth Index (SGI) & $S G I=\frac{\text { Sales }_{\mathrm{t}}}{\text { Sales }_{\mathrm{t}-1}}$ \\
\hline 5 & Depreciation Index (DEPI) & $D E P I=\frac{\frac{\text { depreciation }_{\mathrm{t}-1}}{\mathrm{PPE}_{\mathrm{t}-1}+\text { depreciation }_{\mathrm{t}-1}}}{\frac{\text { depreciation }_{\mathrm{t}}}{\mathrm{PPE}_{\mathrm{t}}+\text { depreciation }_{\mathrm{t}}}}$ \\
\hline & Expenses Index (SGAI) & 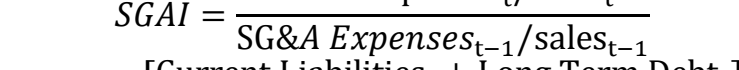 \\
\hline 7 & Leverage Index (LVGI) & 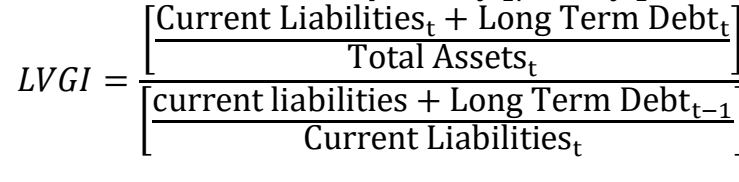 \\
\hline 8 & $\begin{array}{l}\text { Total Acrual to Total Assets } \\
\text { (TATA) }\end{array}$ & TATA $=\frac{\mathrm{NICO}_{\mathrm{t}}-\mathrm{CFO}_{\mathrm{t}}}{\text { Total Assets }_{\mathrm{t}}}$ \\
\hline
\end{tabular}


Pengujian hipotesis digunakan model sebagai berikut:

$$
\begin{gathered}
F R A U D=\alpha-0,023 \text { ACHANGE+0,20OSHIP+0,460LEV+8,309ROA } \\
-2,048 \text { INVENTORY-1,939IND+0,211 AUDCHANGE+e }
\end{gathered}
$$

$\begin{array}{ll}\text { Keterangan: } & \\ \text { ACHANGE } & \text { : rasio perubahan aset selama dua tahun } \\ \text { OSHIP } & \text { : komposisi saham yang dimiliki manajemen } \\ \text { LEV } & \text { : rasio leverage } \\ \text { ROA } & \text { : rasio return on asset } \\ \text { INVEMTORY } & \text { : rasio perubahan persediaan } \\ \text { IND } & \text { :rasio dewan komisaris independen } \\ \text { AUDCHANGE } & \text { : pergantian auditor } \\ \text { e } & \text { : Residual error }\end{array}$

\section{HASIL PENELITIAN}

Tabel 2 berisi statistik deskriptif dari seluruh variabel. Variabel financial stability yang diproksikan dengan rasio perubahan total aset (achange) memiliki nilai rata-rata $-0,012430$ dengan standar deviasi 0,8150992. Nilai tertinggi adalah 0,9428 dan nilai terendah adalah 8.7982. Variabel personal financial need yang diproksikan dengan kepemilikan saham manajerial memiliki nilai rata-rata 0,112555 dengan standar deviasi 0,1870653 . Nilai tertinggi oship adalah 0,9503 dan nilai terendahnya adalah 0,0000 .

Variabel tekanan eksternal yang diproksikan dengan rasio hutang (lev) memiliki nilai rata-rata sebesar 0,511370 dengan standar deviasi 0,4952690. Nilai tertinggi nya adalah 3,2267 dan nilai terendahnya adalah 0,0006 . Variabel target keuangan yang diprokiskan dengan ROA (ROA) memiliki nilai rata-rata sebesar 0,039095 dengan standar deviasi sebesar 0,0665758. Niilai tertingginya yaitu 0,2620 dan nilai terendahnya sebesar $-0,2700$. Variabel nature of industry yang diproksikan dengan perubahan persediaan (inventory) memiliki nilai rata-rata 0,015798 dengan standar deviasi 0,1278416. Nilai tertingginya adalah 1,1304 dan nilai terendahnya -0,4756. Variabel effective monitoring yang diproksikan dengan rasio dewan komisaris independen (ind) memiliki nilai minimum 0,0000 dan nilai tertinggi 0,6667. Rataratanya adalah 0,354895 dengan standar deviasi 0,1015290 .

Variabel rasionalization yang diprksikan dengan pergantian auditor merupakan variabel kategori sehingga memiliki nilai minimum 0 dan nilai maksimum 1. Variabel ini juga memiliki nilai mean 0,26 dan standar defiasi 0,439 . Nilai mean lebih rendah dari 0,5 yang berarti nilai yang sering muncul adalah nilai 0 yaitu perusahaan tidak melakukan pergantian auditor. Variabel kecurangan laporan keuangan juga merupakan variabel kategori yang memiliki nilai minimum 0 dan nilai maksimum. Variabel ini memiliki nilai mean 0,48 Nilai mean lebih rendah dari 0,5 yang berarti nilai yang sering muncul adalah nilai 0 yaitu perusahaan tidak melakukan kecurangan laporan keuangan. 
Tabel 2

Descriptive Statistics

\begin{tabular}{lrrrrr}
\hline & $N$ & Minimum & Maximum & \multicolumn{1}{l}{ Mean } & \multicolumn{1}{c}{ Std. Deviation } \\
\hline ACHANGE & 128 & -8.7982 & .9248 & -.012430 & .8150992 \\
OSHIP & 128 & .0000 & .9503 & .112555 & .1870653 \\
LEV & 128 & .0006 & 3.2267 & .511370 & .4952690 \\
ROA & 128 & -.2700 & .2620 & .039095 & .0665758 \\
INVENTORY & 128 & -.4756 & 1.1304 & .015798 & .1278416 \\
IND & 128 & .0000 & .6667 & .354895 & .1015290 \\
AUDCHANGE & 128 & 0 & 1 & .26 & .439 \\
Kecurangan_Laporan_Keua & 128 & 0 & 1 & .48 & .501 \\
ngan & 128 & & & & \\
Valid N (listwise) & & & &
\end{tabular}

Keterangan:

ACHANGE=rasio perubahana aset, OSHIP=proporsi kepemilikan saham manajerial, $\mathbf{L E V}=$ rasio hutang, ROA=return on assets, INVENTORY=rasio perubahan persediaan, IND=rasio komisaris independen, AUDCHANGE=variabel dummy, 1 jika melakukan pergantian auditor, 0 jika tidak melakukan pergantian auditor, KECURANGAN LAPORAN KEUANGAN=1 jika melakukan kecurangan laporan keuangan, 0 jika tidak melakukan kecurangan laporan keuangan.

Tabel 3

Variables in the Equation

\begin{tabular}{llrrrrrr}
\hline & & \multicolumn{1}{c}{ B } & \multicolumn{1}{c}{ S.E. } & \multicolumn{1}{c}{ Wald } & df & \multicolumn{1}{l}{ Sig. } & \multicolumn{1}{c}{ Exp(B) } \\
\hline Step & ACHANGE (H1) & -.023 & .284 & .007 & 1 & .934 & .977 \\
$1^{\mathrm{a}}$ & OSHIP (H2) & .201 & .988 & .041 & 1 & .839 & 1.222 \\
& LEV (H3) & .460 & .522 & .775 & 1 & .379 & 1.584 \\
ROA (H4) & 8.309 & 3.362 & 6.108 & 1 & .013 & 4060.250 \\
& INVENTORY (H5) & -2.048 & 1.889 & 1.176 & 1 & .278 & .129 \\
IND (H6) & -1.939 & 1.872 & 1.073 & 1 & .300 & .144 \\
AUDCHANGE (H7) & .211 & .421 & .253 & 1 & .615 & 1.236 \\
Constant & -.013 & .714 & .000 & 1 & .986 & .987 \\
\hline
\end{tabular}

Keterangan:

ACHANGE=rasio perubahan aset, OSHIP-proporsi kepemilikan saham manajerial, LEV=rasio hutang, ROA=return on assets, INVENTORY= rasio perubahan persediaan, IND=rasio komisaris independen, AUDCHANGE=variabel dummy, 1 jika melakukan pergantian auditor, 0 jika tidak melakukan pergantian auditor, KECURANGAN LAPORAN KEUANGAN= 1 jika melakukan kecurangan laporan keuangan, 0 jika tidak melakukan kecurangan laporan keuangan

a. Variabel dependent = Kecurngan Laporan Keuangan (FFS)

b. $\alpha=10 \%$

Tabel 3 menunjukkan hasil regresi logistik yang bertujuan untuk membuktikan pengaruh financial stability (achange), personal financial need (oship), external pressure (lev), financial stability (ROA), nature of industry (inventory), effective monitoring (ind), dan rasionalization (audcahnge) terhadap kecurangan laporan keuangan.

Hasil penelitian ini menunjukkan bahwa financial stability yang diproksikan dengan perubahan total aset (achange) tidak berpengaruh terhadap kecurangan laporan keuangan. Hasil ini dapat dilihat dari nilai statistik di mana koefisien $\beta$ financial stability (achange) bernilai 
negatif sebesar -0,023 dengan nilai signifikansi 0,934. Nilai signifikansi 0,934 lebih besar dari 0,1 , sehingga hipotesis pertama di tolak. Hasil penenelitian ini mendukung hasil penelitian yang dilakukan oleh Wahyuni dan Budiwitjaksono (2017), Norbarani (2012), dan Mekarsari (2018). Tinggi rendahnya stabilitas keuangan perusahaan tidak menyebabkan manajemen otomatis melakukan kecurangan untuk meningkatkan stabilitas keuangan. Loebbecke et al (1989) dan Bell et al (1991) dalam Skousen et al. (2009) mengatakan bahwa manajer tidak serta merta memanipulasi laporan keuangan untuk meningkatkan pertumbuhan perusahaan, karena hal tersebut akan memperparah keadaan. Perusahaan akan tetap menjaga citranya agar informasi yang menyebar adalah informasi yang baik dan dapat menarik investor untuk berinvestasi.

Hasil penelitian ini bertentangan dengan Skouesen et al (2009) dan Tiffani (2015) yang menemukan bahwa financial stability (stabilitas keuangan) berpengaruh terhadap kecurangan laporan keuangan. Manajer menghadapi tekanan untuk melakukan kecurangan laporan keuangan ketika financial stability terancam, sehingga memicu terjadinya pelanggaran-pelanggaran yang dilakukan manajemen. Hasil penelitian tersebut mengindikasikan bahwa semakin tinggi kondisi ketidakstabilan keuangan perusahaan, maka kemungkinan perusahaan melakukan kecurangan juga semakin tinggi.

Financial stability merupakan keadaan yang menggambarkan kondisi keuangan perusahaan dalam kondisi stabil. Kondisi stabil suatu perusahaan dapat dilihat dari keadaan asetnya. Penelitian ini menunjukkan bahwa financial stability perusahaan dianggap cukup stabil, hal ini bias dilihat dari rata-rata rasio total aset perusahaan yang rendah dan tidak mengalami perubahan terlalu besar dari tahun ketahun. Penelitian ini membuktikan bahwa perubahan total aset suatu perusahaan tidak berpengaruh terhadap kemungkinan tindakan kecurangan laporan keuangan.

Hasil penelitian ini juga menunjukkan bahwa personal financial need yang diproksikan dengan kepemilikan saham orang dalam kepemilikan tidak berpengaruh terhadap kecurangan laporan keuangan. Hasil ini dapat dilihat dari nilai statistik di mana koefisien $\beta$ personal financial need (oship) bernilai positif sebesar 0,201 dengan nilai signifikansi 0,839. Nilai signifikansi 0,839 lebih besar dari 0,1, sehingga hipotesis kedua di tolak. Hasil ini kemungkinan disebabkan masih rendahnya rata-rata kepemilikian saham orang dalam (kepemilikian manajerial) dalam perusahaan sampel. Hasil penenelitian ini mendukung hasil penelitian yang dilakukan oleh Rani (2016), Tiffani (2015), dan Widarti (2015).

Tiffani (2015) mengatakan bahwa kepemilikan manajerial yang rendah mengindikasikan bahwa perusahaan sampel telah memisahkan antara pemegang saham sebagai pemilik yang mengontrol jalannya perusahaan dan manejer sebagai pengelola perusahaan. Pemisahan yang dilakukan tersebut menyebabkan manajer tidak mempunyai kemampuan dan peluang untuk melakukan kecurangan.

Oship merupakan rasio kepemilikan saham yang dimiliki manajer. Besarnya saham yang dimiliki oleh manajer dapat tercermin dari rasio ini. Rasio OSHIP yang semakin tinggi mengindikasikan bahwa kepemilikan saham oleh pihak manajer di dalam perusahaan tersebut semakin banyak sehingga tindakan untuk melakukan kecurangan menjadi berkurang. Penelitian ini membuktikan bahwa personal financial need yang diproksikan dengan rasio kepemilikan orang dalam tidak berpengaruh terhadap kecurangan laporan keuangan. Penelitian ini bertentang dengan Skousen et al. (2009) yang menyatakan bahwa personal financial need bepengaruh terhdap kecurangan laporan keuangan.

Variabel external pressure yang diproksikan dengan rasio perubahan hutang (lev) tidak berpengaruh terhadap kecurangan laporan keuangan. Hasil ini dapat dilihat dari nilai statistik di 
mana koefisien $\beta$ external pressure bernilai positif sebesar 0,0460 dengan nilai signifikansi 0,379. Nilai signifikansi 0,379 lebih besar dari 0,1 sehingga hipotesis ketiga di tolak. Hasil penenelitian ini mendukung hasil penelitian yang dilakukan oleh Skousen et al. (2009), Ardiyani dan Utaminingsih (2015). Penelitian ini tidak sejalan dengan penelitian yang dilakukan oleh Tiffani (2015) yang menyatakn bahwa external pressure berpengaruh positif terhadap kecurangan laporan keuangan. Penelitiannya menyatakan bahwa semakin besar tekanan dari pihak eksternal maka akan meningkatkan potensi manajemen untuk melakukan kecurangan laporan keuangan.

Leverage dapat digunakan untuk menggambarkan kondisi perbandingan hutang dengan aset yang dimiliki perusahaan. Nilai leverage yang tinggi dikhawatirkan perusahaan tidak bisa melunasi utangnya, karena nilai hutang lebih tinggi dari aset yang dimiliki. Informasi tingkat leverage sangat berguna bagi pihak kreditor yang akan memberikan pinjaman kepada perusahaan (Rani,2016). Perusahaan yang melakukan fraud dengan karakteristik leverage yang rendah bias disebabkan oleh faktor lain seperti adanya tingkat kepercayaan atau hubungan yang baik antara perusahaan dengan kreditor. Perusahaan juga lebih memilih menerbitkan saham kembali untuk memperoleh tambahan modal usaha dari investor tanpa harus melakukan perjanjian utang yang baru (Rani, 2016).

Variabel financial targets yang diproksikan dengan Return on Assets (ROA) dalam penelitian berpengaruh terhadap kecurangan laporan keuangan. Hasil ini dapat dilihat dari nilai statistik di mana koefisien $\beta$ financial targets bernilai positif sebesar 8,309 dengan nilai signifikansi 0,013. Nilai signifikansi 0,013 lebih kecil dari 0,1 , sehingga hipotesis ketiga di terima. Hasil ini mengindikasikan bahwa semakin tinggi financial targets yang diinginkan maka kecurangan laporan keuangan juga akan meningkat. Hasil penelitian ini mendukung hasil penelitian yang dilakukan oleh Skousen et al. (2009) dan Widarti (2015).

Penelitian ini bertentangan dengan Tiffani (2015), Yuni (2017), dan Rani (2016) yang menyatakab bahwa external pressure tidak berpengaruh terhadap kecurangan laporan keuangan. Tiffani (2015) menyatakan bahwa kecurangan laporan keuangan tidak dipengaruhi oleh ROA karena manajer beranggapan target ROA masih wajar dan bias dicapai. Besarnya target ROA ini tidak menjadikan tekanan bagi manajemen sehingga kecurangan laporan keuangan bisa diminimalisir. Return on Assets merupakan rasio profitabilitas. Rasio ini digunakan untuk mengukur berapa laba yang dihasilkan dengan memanfaatkan assets yang dimiliki. Laba yang dipeoleh sesuai dengan target keuangan akan memicu para investor untuk berinvestasi terhadap perusahaan tersebut. Target laba yang telah ditetapkan akan dicapai oleh manajemen dengan berbagai cara, sehingga memungkinkan manajemen memanipulasi laba dan menyajikan laporan keuangan secara tidak wajar (Widarti, 2015). Penelitian ini membuktikan bahwa ROA berpengaruh positif signifikan terhadap kecurangan laporan keuangan.

Variabel nature of industry yang diproksikan dengan rasio perubahan persediaan (inventory) tidak berpengaruh terhadap kecurangan laporan keuangan. Hasil ini dapat dilihat dari nilai statistik di mana koefisien $\beta$ nature of industry bernilai negative sebesar -2,048 dengan nilai signifikansi 0,278. Nilai signifikansi 0,379 lebih besar dari 0,1, sehingga hipotesis kelima di tolak. Hasil penenelitian ini mendukung hasil penelitian yang dilakukan oleh Rani (2016).

Persediaan menggambarkan keadaan perusahaan berkaitan dengan perubahan persediaan dalam penjualan. Peneliaian subjektif diperlukan dalam menilai persediaan, terutama dalam memperkirakan absolete inventory (Rani, 2016). Penilaian subjektif ini dimanfaatkan oleh manajemen sebagai alat untuk memanipulasi laporan keuangan. Hasil penelitian ini tidak sejalan dengan teori fraud triangle. Hasil yang tidak sesuai ini disebabkan karena pada proksi peluang 
terdapat beberapa proksi yang memungkin mampu mendeteksi kecurangan laporan keuangan. Hasil penelitian ini diperkuat oleh penelitian Sukirman (2013). Penelitian tersebut menyatakan bahwa hasil ini bertentangan dengan beberapa teori yang ada bahwa nominal yang tercantum dalam akun di dalam laporan keuangan mayoritas berdasarkan estimasi dan subjective judgment. Summers and Sweeney (1998) mengatakn bahwa manajemen harus focus pada beberapa akun yang berpotensi besar untuk dilakukan manipulasi.. Hasil penelitian ini menyatakkan bahwa tidak ada pengaruh nature of industry terhadap kecurangan laporan keuangan.

Hasil penelitian ini menunjukkan bahwa variabel effective monitoring yang diproksikan dengan rasio komisaris independen (ind) tidak berpengaruh terhadap kecurangan laporan keuangan. Hasil penelitian ini sejalan dengan Martantya (2013) dan tidak mendukung hasil penelitian Tiffani (2015) serta Skousen et al (2009). Hasil ini didasarkan pada hasil pengujian statistik dimana nilai signifikansi 0,300. Nilai signifikansi 0,300 lebih besar dari 0,1, sehingga hipotesis keenam ditolak.

Pengukuran dalam penelitian ini merupakan rasio dari anggota dewan komisaris yang independen dalam suatu perusahaan. Variabel effective monitoring yang diproksikan dengan anggota dewan komisaris independen mewakili konsep opportunity. Teori fraud triangle menjelaskan bahwa kecurangan terjadi karena adanya peluang. Penelitian ini tidak membuktikan teori tersebut, karena hipotesis terkait variabel effective monitoring ditolak. Pengangkatan dewan komisaris independen dalam perusahaan sampel kemungkinan hanya untuk memenuhi regulasi saja. Pengangkatan dewan komisaris independen tidak dimaksudkan untuk menegakkan GCG untuk mencegah upaya salah saji laporan keuangan. Hasil penelitian ini mengindikasikan bahwa keberadaa anggota dewan komisaris independen belum bekerja secara optimal. Penambahan dan pengurangan anggota dewan komisari independen dilakukan hanya untuk memenuhi ketentuan formal saja (Boediono, 2005).

Variabel rasionalization yang diproksikan dengan pergantian auditor (Audchange) tidak berpengaruh terhadap kecurangan laporan keuangan. Hasil penelitian dapat dilihat dari pengujian statsitik di mana nilai signifikan sebesar 0,615. Nilai signifikan yang lebih besar dari 0,1 , sehingga hipotesis ketujuh ditolak. Penelitian ini sejalan dengan penelitian yang dilakukan oleh Summer dan Sweeney (1989), Skousen et al (2009) yang menyatakan bahwa pergantian auditor tidak mempengaruhi terjadinya kecurangan laporan keuangan.

Audit laporan keuangan dilakukan oleh auditor. Auditor adalah pengawas penting dalam audit suatu laporan keuangan perusahaan. Informasi-informasi kecurangan laporan keuangan suatu perusahaan akan diketahui oleh auditor. Penelitian ini menunjukkan bahwa perusahaan yang tidak melakukan pergantian auditor lebih banyak dari perusahaan yang melakukan pergantian auditor. Pergantian auditor dalam perusahaan sampel kemungkinan hanya untuk mematuhi regulasi pemerintah. Regulasi tersebut adalah Peraturan Pemerintah Republik Indonesia Nomor 20 Tahun 2015 tentang Praktik Akuntan Publik pasal 11, di mana pemberian jasa audit dibatasi paling lama adalah untuk 5 (lima) tahun buku berturut-turut. Keputusan ini menuntut perusahaan untuk melakukan pergantian auditor, sehingga kemungkinan perusahaan mengganti auditor bukan untuk menghindari kecurangan.

\section{KESIMPULAN, IMPLIKASI, KETERBATASAN, DAN SARAN Kesimpulan}

Penelitian ini bertujuan untuk memperoleh bukti empiris mengenai pengaruh variabel financial stability, personal financial need, externalpressure, financial target, effective monitoring, dan rasionalization terhadap kecurangan laporan keuangan. Hasil penelitian menunjukkan bahwa 
variabel financial stability yang diproksikan dengan rasio perubahan total aset (achange) tidak berpengaruh terhadap kecurangan laporan keuangan. Variabel tekanan personal financial need yang diproksikan dengan rasio kepemilikan manajerial atau kepemilikan saham orang dalam (oship) tidak berpengaruh terhadap kecurangan laporan keuangan.Variabel external pressureyang diproksikan dengan rasio perubahan hutang (lev) tidak berpengaruh terhadap kecurangan laporan keuangan.

Variabel financial targets yang diproksikan dengan ROA berpengaruh terhadap kecurangan alporan keuangan.Variabel nature of industry yang diproksikan dengan rasio perubahan persediaan (INVENTORY) tidak berpengaruh terhadap kecurangan laporan keuangan. Variabel effective monitoring yang diproksikan dengan rasio anggota dewan komisaris independen tidak berpengaruh terhadap kecurangan laporan keuangn. Variabel rasionalization yang diproksikan dengan pergantian auditor (AUDCHANGE) tidak berpengaruh terhadap kecurangan laporan keuangan.

\section{Implikasi}

Hasil penelitian ini dapat menjadi rujukan bagi investor, akademisi, perusahaan, auditor dan pemerintah. Investor maupum pemakai laporan keuangan diharapkan dapat lebih memahami dan menganalisa faktor-faktor penyebab terjadinya kecurangan laporan sebelum memutuskan untuk berinvestasi, karena target keuangan yang tinggi dalam suatu perusahaan berkemungkinan akan melakukan kecurangan. Auditor dapat lebih berhati-hati dalam memberikan opini audit terkait laporan keuangan untuk menghindari beberapa kecurangan yang sulit untuk dideteksi. Perusahaan diharapkan mampu menjalankan adanya fungsi komisaris independen. Komisaris independen bukan hanya sekedar pelengkap untuk mematuhi peraturan yang ditetapkan oleh OJK tetapi untuk lebih mengawasi jalannya perusahaan sehingga kecurangan dalam laporan keuangan dapat diminmalisir.

\section{Keterbatasan Penelitian}

Keterbatasan dari penelitian ini adalah sebagai berikut. Pertama, perusahaan yang dijadikan sampel perusahaan adalah perusahaan manufaktur dengan pengambilan sampling menggunakan metode purposive sampling, sehingga hasil penelitian tidak dapat menggenerelaisasi seluruh sektor industry karena sektor industry tersebut memiliki karekteristik yang berbeda. Kedua, nilai Negelker $R$ Square sebesar 0,086. Nilai ini menunjukkan bahwa variabel financial stability, personal financial need, external pressure, financial target, nature of industry, effective monitoring, dan rasionalization secara bersama-sama mempengaruhi variabel dependen sebesar $8,6 \%$ dan $82,4 \%$ dipengaruhi oleh faktor lain yang tidak diteliti dalam penelitian ini.

\section{Saran}

Hasil kesimpulan dan keterbatasan penelitian yang telah diuraikan sebelumnya, maka saran yang diajukan sebagai berikut. Peneliti selanjutnya yang ingin meneliti kembali variabel yang sama agar memperluas populasi penelitian dan menggunakan variabel dependen lain seperti perataan laba seperti yang digunakan dalam penelitian Hribar, Kravet, dan Wilson (2014). Peneliti selanjutnya, disarankan menambahkan variabel independen yang lain, seperti ineffective monitoring, organizational structure, dan lain sebagainya. 


\section{DAFTAR PUSTAKA}

Aghghaleh, S. F, Iskandar, T. M. dan Mohamed, Z. M. (2014). Fraud Risk Factors of Fraud Triangle and the Likelihood of Fraud Occurrence: Evidence from Malaysia. Universiti Kebangsaan Malaysia, Malaysia.

Albrecht, C., Turnbull, C., Zang, Y. dan Skousen, C.J. (2010). The relationship Between South Korean Chaebols and Fraud. Management Research Review, 33(3), 257-268.

Amara, I., Amar, A.B., dan Jarboui, A. (2013). Detection of Fraud in Financial Statement: French Companies as Case Study. International Journal of Academic Reaserch in Accounting, Finance and Management Sciences, 3(3).

Beasley, M. (1996). An Empirical Analysis of the Realtion between Board of Director Composition and Financial Statement Fraud. The Accounting Review, 71(4), 443-465.

Beneish, M. (1997). Detecting GAAP violation: Implications for assessing earnings management among firms with extreme financial performance. Journal of Accounting and Public Policy, 16(3), 271-309.

Brennan, N. M. dan Mcgrath, M. (2007). Financial Statement Fraud: Some Leasson from US and European Case Studies. Australian Accounting Review, 17(24):49-61.

Cressey, D. (1953). Other people's money, dalam: Detecting and Predicting Financial Statement Fraud: The Effectiveness of the Fraud Triangle and SAS No. 99, Skousen et al. 2009. Journal of Corporate Governance and Firm Performance, 3, 53-81.

Dechow, P. M., Sloan, R. G., dan Sweeney, A. P. (1994). Detecting Earning Management, The Accounting Review, 70(2).

Ernst danYoung. (2009). Detecting Financial Statement Fraud: What Every Manager Needs to Know.

Ghozali, I. (2013). Aplikasi Analisis Multivariate Dengan Program IBM SPSS 21. Semarang: Universitas Diponegoro.

Intal, T. \& Do, L. T. (2002). Financial Statement Fraud-Recognition of Revenue and the Auditor's Respondbilility for Detecting Financial Statement Fraud. Thesis. Goteborg University.

Koroy. (2008). Pendeteksian Kecurangan (Fraud) Laporan Keuangan oleh Auditor Eksternal. STIE Nasional Banjarmasin, 22-31.

Lou, Y. dan Wang, M-L. (2009). Fraud Risk Factor of The Fraud Triangle Assessing The Likelihood Of Fraudulent Financial Reporting. Journal of Business \& Economics Research.

Martantya, D. (2013). Pendeteksian Kecurangan Laporan Keuangan Melalui Faktor Risiko Tekanan dan Peluang (Studi Kasus pada Perusahaan yang Mendapat Sanksi dari Bapepam Periode 2002-2006), ISSN 2337-3806.

Mulford, C. dan Comiskey, E. (2010). The Financial Numbers Game Detecting Creative Accounting Theory. New York: John Wiley and Sons, Inc.

Nguyen H. H., Widodo, S., Momordica L., In: Medicinal and Poisinous Plant Research of SouthEast Asia 12. De Padua L. S. N. Bunyapraphatsana and R. H. M. J. Lemmens (eds.). Pudoc Scientific Publisher. Wageningen, the Netherland;1999. p.353-359.

Norbarani, L. (2012). Pendeteksian Kecurangan Laporan Keuangan Dengan Analisis Fraud Triangle Yang Diadopsi Dalam Sas No.99. Skripsi. Fakultas Ekonomika dan Bisnis, Universitas Diponegoro.

Ratmono, D., Yuvita, A.D., dan Purwanto, A. (2014). Determinan Kecurangan Laporan Keuangan: Pengujian Teori Fraud Triangle. Diponegoro Journal of Accounting. 
Rezae, Z. (2002). Financial Statemen Prevention and Detection. New york: John Wiley \& sons, Inc.

Skousen, C. J., Smith, K. R. dan Wright, C. J. (2008). Detecting And Predicting Financial Statemenr Fraud: The Effectiveness Of The Fraud Triangle And SAS No 99. Advances in Financial Economics, 13.

Skousen, C.J., Smith, K.R. dan Wright, C.J. (2009). Detecting and Predicting Financial Statement Fraud: The Effectiveness of the Fraud Triangle and SAS no. 99. Journal of Corporate Governance and Firm Performances, 13, 53-81.

Spathis, C.T. (2002). Detecting false financial statement using published data: some evidence from Greece. Managerial Auditing Journal, ISSN 0268-6902.

Sukirman dan Sari, M. P. (2013). Model Deteksi Berbasis Fraud Triangle (Studi Kasus Pada Perusahaan Publik Di Indonesia). Jurnal Akuntansi \& Auditing. 9.

Summers, S., dan Sweeney, J. (1998). Fraudulent misstated financial statements and insider trading: An empirical analysis. The Accounting Review, 73, 131-146.

Tuanakotta, T. M. (2010). Akuntansi Forensik \& Audit Investigatif. Jakarta: Salemba Empat.

www.idx.co.id

www.tirto.id

-----, 2002. Statement on Auditing Standards (SAS) No. 99: Consideration of Fraud in Financial Statement Audit. New York: AICPA 